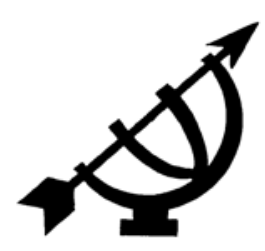

\title{
A perspective on (neo-)Darwinism (2010) ${ }^{1}$
}

\author{
D.F.M. Strauss \\ Faculty of the Humanities \\ University of Free State \\ BLOEMFONTEIN \\ E-mail: dfms@cknet.co.za
}

\begin{abstract}
A perspective on (neo-)Darwinism (2010)

A perspective on (neo-)Darwinism first of all has to account for those assumptions derived from the humanities, causing neoDarwinism not to be a purely special scientific or natural scientific theory. A discussion of the many-sidedness of living entities highlights the difficulties surrounding a definition of biology. Attention is briefly given to the physicalism of Darwin's 1859 work before the quest for origins is discussed. These considerations pave the way for an assessment of striking shortcomings in the thought of Darwin and his followers. In particular, modern nominalism is identified as an important source for neo-Darwinism, especially manifest in the idea that organisms are not types and do not have types (Simpson). Darwin's idea of incremental (continuous) change both in respect of the genesis of a complex organ (or the origination of the first living entity) and of successive fossil forms contradict the current state of affairs - and the same applies to his own radical idea that "injurious" variations will be eliminated immediately by natural selection, for it cannot be reconciled to the role of mutations in neo-Darwinian theory. In addition neoDarwinian paleontologists pointed out that evolution requires intermediate forms and paleontology does not provide them (Kitts) and explicitly confessed that they have paid lip-service to the idea of change while they knew all the time that it was not true (Eldredge): the dominant theme of the paleontological record is stasis, constancy - a type appears and remains constant for millions of years before it disappears (Gould). The
\end{abstract}

1 This article was first presented as a Stoker Lecture in Potchefstroom on 22 October 2009. 
supposition of incremental continuity received a further blow from the "Cambrian explosion", the "nasty fact" that most "major animal groups appeared simultaneously" about 530 million years ago. A few aspects of the uniqueness of humankind are treated as well as the confused picture found in an attempt to synthesise neo-Darwinism and Christianity. In an appendix a brief assessment is added concerning the pretentions of neoDarwinism.

\section{Opsomming}

\section{'n Perspektief op die (neo-)Darwinisme (2010)}

'n Perspektief op die neo-Darwinisme moet allereers rekenskap gee van daardie geesteswetenskaplike aannames wat daartoe gelei het dat die neo-Darwinisme nie 'n suiwer vakwetenskaplike teorie en ook nie 'n suiwer natuurwetenskaplike teorie is nie. 'n Bespreking van die veelsydigheid van lewende dinge belig die probleme verbonde aan 'n definisie van die biologie. Aandag is vlugtig gegee aan die fisikalisme van Darwin se 1859-werk alvorens die sug na oorspronge bespreek is. Hierdie oorwegings het die weg gebaan vir 'n beoordeling van die treffende tekortkomings in die denke van Darwin en sy volgelinge. In die besonder is die moderne nominalisme geïdentifiseer as 'n belangrike bron vir die neo-Darwinisme, veral gemanifesteer in die idee dat organismes nie tipes is of tipes kan hê nie (Simpson). Darwin se idee van geleidelik (kontinue) verandering ten opsigte van die ontstaan van 'n komplekse orgaan (of die ontstaan van die eerste lewende entiteit) asook van opeenvolgende fossielvorms is in stryd met die huidige stand van sake - en dieselfde geld vir sy eie radikale siening dat "nadelige" variasies onmiddellik deur natuurlike seleksie geëlimineer sal word, want dit kan nie versoen word met die rol van mutasies in die neoDarwinistiese teorie nie. Bykomend het neo-Darwinistiese paleontoloë daarop gewys dat evolusie tussenvorms vereis en dat die paleontologie dit nie lewer nie (Kitts). Hulle het openlik bely dat hulle lippediens gelewer het aan die vermeende verandering in the paleontologie terwyl hulle al die tyd geweet het dit is nie waar nie (Eldredge): die dominante tema van die paleontologie is stasis, konstantheid - 'n tipe verskyn en bly konstant vir miljoene jare alvorens dit verdwyn (Gould). Die aanname van geleidelik-kontinue verandering het ' $n$ verdere terugslag ontvang van die "Cambrian explosion", die "nasty fact" dat die meeste "major animal groups appeared simultaneously" omtrent 530 miljoen jaar gelede. Enkele fasette van die uniekheid van die mens is aan die orde gestel asook die verwarde prentjie wat aangetref word in 'n poging om die neo-Darwinisme met die Christendom te versoen. In 'n aanhangsel word 'n oorsigtelike 
beoordeling van die pretensies van die neo-Darwinisme behandel.

\section{Orientation}

Highlighting shortcomings and problems within the Darwinian and neo-Darwinian legacy naturally has to cover a wide range of issues and perspectives that are not always necessarily directly connected to each other. However, in this article they are integrated within the overall aim to obtain a critical perspective on this intellectual legacy within the West.

The historically significant year, 1859, marks the appearance of Darwin's work On the origin of species by means of natural selection; or, The preservation of favoured races in the struggle for life. The appearance of this book inspired reflections on its impact from various corners during 2009, coupled with Darwin's bicentenary (he was born in 1809). This article aims at contributing to this appraisal of the work and influence of Darwin and its reinforcement through the subsequent development of neo-Darwinism. ${ }^{2}$ Note that the misunderstanding is widespread that there is just one theory of "evolution". We shall see below that twentieth-century biology in fact knows diverse (and mutally conflicting) biological orientations. In addition, Darwin's place within the intellectual tradition of the West will have to be explained as well. This entails that we will have to assess whether or not the (neo-)Darwinian theory of evolution is a special scientific theory, that is to say. Is it a truly biological theory? Of course the other side of the coin suggests that this theory of evolution exceeds the boundaries of biology as a special science.

We commence our discussion by focusing on a number of unavoidable foundational issues. In the first instance we shall reflect on the inevitable pre-scientific awareness of the diversity within reality as a foundational condition for a discipline such as biology. The discontinuity entailed in this diversity implies that the assumed continuous transition from the non-living to the living and within the living from the lowest to the highest forms harbours a speculative, and therefore, problematic stance. By embarking upon a closer analysis of the

2 In the main text and in the appendix this appraisal will briefly pay attention to questions not normally asked, and considerations usually not contemplated, such as whether or not the (neo-)Darwinian theory of evolution is a purely biological theory (special scientific in nature); if it is objective and neutral; whether it is a natural scientific theory; and whether it finds sufficient support in factual data. 
many-sidedness of living entities the idea of a diversity of functional aspects will be further substantiated.

\section{Defining biology}

\subsection{What is plant science and what is a plant?}

Suppose biology is subdivided in plant science and animal science leaving aside for the moment the currently fasionable practice to distinguish up to five realms (kingdoms) among living entities - and then consider the question: What is botany? Suppose that the answer is: "Botany (plant science) is a study of plants". Whoever accepts this definition has to concede that formulating it does not form a part of practicing the discipline of botany. Defining botany indeed is not a study of plants, but merely a study of the study of plants. This argument does not claim that knowledge of botany is underestimated or that the specialist knowledge of a botanist is disregarded. Surely a botanist is well-equipped to provide such a definition. Yet, the question is not who provides the definition, but rather what is the nature of the definition? It is clear that the answer which we have in mind does not form a part of botany.

Biologists may be inclined to argue that only a competent botanist will be able to articulate a proper definition of botany. Without disagreeing from this argument, however, we have to note that the crucial issue is not who gives the definition, but what is the nature of the definition. Since defining botany is not a study of plants, formulating such a definition obviously does not belong to the discipline of botany. The theoretical domain within which scholarly disciplines (that is, the special sciences) are defined, exceeds the boundaries of any specific special science. The question what science as such is (and in any particular instance) therefore precedes the differentiation and specialisation of all the academic disciplines - for that reason it belongs to the discipline of philosophy which has the task of investigating foundational questions such as these.

Suppose we change the above-mentioned question and ask: Who can tell us what a plant is? Is a botanist not best qualified to answer this new question? The problem then is that one cannot account for the first person who started to investigate plants in a scientific way, for at that stage no botanist was available to tell us what a plant is! In other words, without the prior ability to distinguish between material things, plants and animals, no person would be able to start the study of plants, for in practical terms one may just as well end up studying physical entities or animals believing that they are plants. 
The sole and ultimate basis for identifying plants as plants is therefore given in our pre-scientific experience of different kinds of entities, reflecting the diversity within reality. Of course plant scientists can deepen and enrich our pre-scientific knowledge, but it can never replace it.

\subsection{The many-sidedness of living entities}

Since plants, animals and human beings are all living entities, biologists are assumed to be able to explain what "life" is, particularly because it is a wide-spread practice among them to speak of "life" as something concrete, for example when they discuss the "origin of life". Of course the cell is the smallest living entity known (viruses are dependent upon cells and are therefore, strictly speaking, not alive in the full sense of the term).

Let us approach this problem by first asking whether any living thing is fully alive - alive in its totality and in all it parts. This question presupposes the possibility to specify what are to be considered as genuine parts of a living entity which, in turn, presupposes an insight into the nature of the whole-parts relationship. In order to account for the latter, however, an account is required of two related issues: the difference between aspects (functions, modalities) and entities; and the inter-connections between various aspects (and entities).

All entities are many-sided or multi-aspectual, in the sense that their existence is never exhausted by any one of their modal functions only. For example, although material entities are currently understood as physical entities, they also simultaneously function within the aspects of number, space, and movement. 3 Modal or aspectual laws hold universally for all possible kinds of entities, whereas any specific type of entity solely conforms to a specified type of law merely applicable to a limited class of entities. The type law for an atom is specified because it holds for atoms only (and not everything

3 The history of the concept of matter shows how attempts were made to characterise material entities in numerical terms ("everything is number" - the Pythagoreans), in spatial terms (extension remained the essential property of material entities up to Descartes and Kant), in kinematic terms (the main tendency of classical physics is mechanistic - with Heinrich Hertz as its last, late nineteenth century, prominent representative). A detailed analysis of this development is found in Strauss (2006). 
is an atom), but it still displays (a specified) universality, because it holds for all atoms. 4

Since the modal-functional meaning of space reflects its core meaning in continuous extension it follows that the continuity of a spatial subject (such as a straight line) entails that every part is connected to every other part - that its parts cohere. When all its parts are present the whole is given. For this reason continuity is synonymous with being-connected, with what is coherent and with the relation between a whole and its parts. Therefore the whole-parts relation has its original seat within the spatial aspect. Both physical space and mathematical space are extended - the similarity between them. However, notwithstanding this similarity, there are also differences, for whereas the original meaning of spatial extension entails that it is both continuous and infinitely divisible, physical space is neither continuous, nor infinitely divisible (because it is bound to the quantum structure of energy (cf. Hilbert, 1925:164). When two aspects are similar in the respect in which they differ, we meet an analogy. Therefore physical extension analogically refers back to spatial extension. A spatial whole is homogenous - every part is of the same nature. Even in the case of physical entities, their parts may be similar, as observed from the fact that a part of salt is still salt (with a $\mathrm{NaCl}$ chemical structure). A biotical whole is heterogenous, for although a part of a horse is a "horse-part", it is, nonetheless, not a horse (cf. Oeing-Hanoff, 1976:306). 5 Although the different organs of a horse differ among themselves and from similar organs found in other animals, they nonetheless all share the same biotic property of being (part-) organs of a horse. This feature therefore represents, within the heterogenous biotic whole-parts relation, an element of homogeneity.

In terms of the question regarding the true parts of a living entity, it is clear that the living organism of a living entity indeed evinces such an organic whole-parts relation. 6 Holistic approaches employ the

4 We shall return to Darwin and neo-Darwinism which accept universal modal (physical) laws, but deny biotical type laws.

5 It must be acknowledged, however, that from a biotic perspective, the different organs of a horse all exhibit the organic feature of being integrated in the living organism of the horse. For this reason, the heart of a horse differs from that of a cow.

6 Note that if the whole-parts relation has its original seat within the aspect of space (cf. Strauss, 2009:60-61, 224-226), and if the living organism of living entities displays a whole-parts relation, then an organic whole-parts relation also 
idea of integrated organic parts in this regard, designated in German as Glieder (Afrikaans: geledinge). The reason for making a distinction between die living organism of a living entity and the entity itself is that within a living entity one also finds its non-living building blocks - atoms, molecules and macro-molecules.

Nonetheless, this does not exhaust the complexity of what is at stake, because every organ of a living entity is constituted by a complex arrangement of atoms, molecules and macro-molecules - and the latter certainly are not alive. The neo-Darwinian paleontologist, Simpson, correctly holds that, since molecules are not alive, the expression "molecular biology" is actually self-contradictory (Simpson, 1969:6). A discipline such as biochemistry does not fall into the same pitfall, because it focuses on the chemical (molecular) basis of the biotic functions of living entities without implicitly claiming that molecules as such are alive.

Therefore, it cannot be denied that, within living things, non-living entities are also present, namely atoms, molecules and macromolecules. The conclusion is inevitable: a living entity appears to be at once a "mixture" of the "living" (its organs) and the "non-living" (its molecular basis). In other words, it is not alive through-and-through - it seems to be "alive" and "non-living" at the same time - thus demonstrating that the reifying mode of speech, referring to "life" as if it is an independent entity, is untenable.

The predominant (neo-)Darwinian tradition in modern biology, has a physicalist inclination that opts for a view in which the biotic side of living entities is completely reduced to the interaction between atoms, molecules and macro-molecules. Vitalistic, holistic and organismic approaches, by contrast, do acknowledge what is sometimes referred to as the irreducibility of "life" - without realising, however, that this is still a reifying mode of speech, talking about "life" as if it is a thing, instead of merely being one among many aspects of living entities. Let us briefly examine the multi-aspectual nature of living things. Although atoms, molecules and macro-molecules as such are not alive, it is mistaken to claim that they are "dead". The qualification dead only applies to things that were alive - thus eliminating both expressions: "living matter" and "dead matter"! The German physicist, Von Weizsäcker (1993:32) is therefore fully justified in in-

analogically reflects the spatial whole-parts relation. The continuity of an extended spatial figure - such as a straight line - is connected in all its parts, but if all the cohering parts are present then we have the whole of the line. 
troducing the new term unbelebt, designating that which is not, and has never been alive.

Let us now briefly mention the active (or: subject) functions of living entities within the first four aspects of reality. No one can deny the unity ("oneness") of living things - the unity in the multiplicity of their organic functioning. The phrase "organic functioning" entails the existence of a multiplicity of organic activities. In our everyday experience, this is intimately connected to an awareness of the intact nature of a living entity, its biotic wholeness, serving as a precondition for its continued processes of life (generally growing, i.e. differentiation and integration), maturation, ageing and dying. Therefore living entities indeed also occupy space, display movement and function thermodynamically as open systems - and all these functions are guided by their qualifying biotic function. ${ }^{7}$ What is indeed remarkable is that a living entity like the cell, not merely functions in a unique entitary way within the physical aspect of reality. Karl Trincher (1985:336) identified four "macroscopic"8 characteristics from which the physical uniqueness of a living cell is evident, which include the following:

- spatial macroscopy, which defines the cell as a spatially delimited surface;

- temporal macroscopy, which determines the finite time in which the energy cycle of the cell occurs;

- the isothermal nature of the cell, which is responsible for the constancy of temperature throughout the cell; and

- the persistent positive difference between the higher internal temperature of the cell and the lower external temperature of the environment adjacent to the cell surface.

7 In terms of thermodynamically open systems, any living entity, from a physical perspective, prevails in a state of high statistical improbability. This physical instability is a precondition for the biotical stability of such entities, captured by saying that they are healthy. Biotic stability presupposes physical instability and physical stability implies biotic instability (a sign that death is on its way!). The neo-vitalist biologists who succeeded Hans Driesch, in particular SchubertSoldern, introduced the phrase "instability factor" as substitute for Hans Driesch's entelechie (cf. Schubert-Soldern, 1959:62, 68; 1962:102 ff.).

8 Note that Trincher employs the term macroscopic in the sense or "overall" (the opposite of "restricted to some or other part") and not in the sense of large (as opposed to small). 
As an aspect of reality, life therefore pertains to the how of entities and not to their concrete what. Just like physical entities, the existence of biotic entities also is never enclosed in any single aspect, not even within their qualifying biotic aspect. Particularly in the vitalist tradition - which sees life as independent variations of an immaterial vital force - this becomes a problem. That the biotic aspect of living entities cannot be seen on its own, i.e. separated from the inter-modal coherence in which it is fitted, is confirmed by the analogies intrinsic to the structure of the biotic aspect. Even the expression life force (vital force), which is so often chosen by vitalism (but remarkably enough, has been replaced with other terms like Gestaltungsfaktor or Zentralinstanz in the second half of the twentieth century), can never indicate or typify the alleged separated existence of the biotic aspect - simply because it unmistakably represents a physical analogy within the modal structure of the biotic aspect. The term force finds its original, i.e. non-analogical, modal seat in the physical aspect of energy operation.

From the preceding remarks, we can deduce that the term life refers to the unique core meaning of the biotic aspect of reality. Particularly physicalist materialism does not acknowledge the uniqueness of the biotic aspect. The original version of Darwin's book, published in 1859 , certainly does not advance a truly biological theory at all. It acknowledges only (physical) "laws of nature" but nowhere speaks of any biotical laws of nature. Its main emphasis is on change, at the cost of constancy (cf. Strauss, 2007).

Through his 1859 work Charles Darwin undoubtedly irrevocably changed the face of modern biology. Before he published it, biological thought was largely dominated by the Platonic idea that living things are mere copies of unchanging, static, eternal (super-sensory) ideal forms, as well as the vitalistic Aristotelian tradition, with its emphasis on purposefulness (finality/teleology). The biological systematic classification of Ray (1627-1705) and Linnaeus (17071778) continued the Platonic legacy and it captured the minds of biologists up to the present, for representatives of idealistic morphology are also found in the twentieth century. These include Dacqué (cf. 1935; 1940; 1948), Troll (1951; 1973), Wolf (1951), Leinfeller (1966) and Heitler (1976). Troll's work of 1973 is a standard (more than 1000 page) botany textbook. According to Troll, the foundation of comparative morphology is to be found in ideas (in the platonic sense), which serve to order the "inner articulations of our intuition" by means of which types as Urbildliche Einheiten (primordial image- 
like units) become the subject matter of biology (cf. Ungerer, 1966: 232).

\section{The physicalism of Darwin's 1859 work}

During the past 150 years, diverse trends of thought emerged within biology - constantly introducing alternative modes of explanation. The brief overview given below broadens the perspective on neoDarwinism amidst different biological trends of thought.

Consider the mechanistic orientation (Eisenstein, 1975a), the physicalistic approach (neo-Darwinism), neo-vitalism (Driesch, 1929; Sinnott, 1963; 1972; Schubert-Soldern, 1959; 1962; Haas, 1959; 1968; Heitler, 1976); holism (Meyer, 1964; 1965); emergence evolutionism (C. Lloyd-Morgan, Richard Woltereck, Bernard Bavink, 1954; Polanyi, 1967; 1968; 1969); the organismic biology of Von Bertalanffy (1973); and pan-psychism (De Chardin [cf. Duyvené de Wit, 1962], Rensch, 1959; 1968; 1969; 1971, 1973); recent complexity theory (Behe's notion of "irreducibly complex systems" - cf. Behe, 2003) and the idea of "intelligent design" that surfaced more recently - not on the basis of insufficient factual knowledge, but supported by scholars with highly specialised natural scientific competencies (cf. Dekker et al., 2006).

For the mechanistic (physicalistic) approach, everything is material in principle, and physically determined, which implies that any terms that appeal to the actual biotic aspect of living things are problematic. Conversely, vitalism searches for immaterial life plans currently designated as reflecting an intelligent design - in order to account for the actual nature of "life". These life plans are sometimes designated as formative factors or central instances. It also makes it difficult to speak of "living matter" from the perspective of this approach - a problem that a vitalistic biologist like Haas admits with his emphasis on the fact that physical substances maintain their "being and working" "subsequent to their assimilation" in living things. Understandably, therefore, Haas is also critical of the habit of speaking of "living matter" - according to him, the biochemists and cell physiologists do not know of any "living matter" with "secret vital characteristics" (Haas, 1968:24). He prefers to speak of the material substratum of organisms (Haas, 1968:20-40).

This approach rejects what Haas sees as Aristotle's "monistic vitalism" - and at the same time he draws conclusions about his own approach: 
Organisms therefore consist essentially of two realities which are distinguished from each other, a material and a nonmaterial component; it consequently possesses, viewed ontologically, a dualistic constitution (Haas, 1968:39).

\section{The quest for origins}

It appears that intrinsic to human thinking is an urge towards what is considered to be ultimate, in the sense of unconditional and independent existence - upon which whatever else there may be depends (cf. Clouser, 2005:35-41).

Overestimating human intellectual abilities is almost as old as humankind itself. Contemporary physics (cosmology) pretends to account for "creation" whereas in fact it theorises over a presumed unique event lying at the boundaries of our (physical experience). The "Big Bang" is sometimes portrayed as departing from a primordial initial hot and condensed condition that precedes time and space. In some respects the mode of speech attached to the Big Bang hypothesis closely imitate the theological tradition of a negative theology - where one cannot say what God is like, but only state what God is not. Of course in all instances of a negative theology one always finds one or another last remnant of a positive characterisation. In the case of the Big Bang it is therefore not surprising that size and heat play a crucial role - think about terms such as density and temperature. Hubble and Lemaître contributed to the idea of the expanding universe. The equations formulated by Alexander Friedmann are based upon Einstein's General theory of relativity and they presuppose the conditioning role of the first four aspects of reality - number, space, the kinematic and the physical. However, Gentry questions the expansion postulate, arguing that "the universe is relativistically formatted in accordance with the Schwartzschild static spacetime solution of the field equations, not the Friedmann-Lemaître spacetime" (cf. Gentry, 2001:1).

Whatever the outcome of this controversy may be, it cannot qualify as an account of creation. Dating this primordial event to almost 14 billion years ago appeals to time measurement and time measurement always involves the duration of a process. Any time duration is always delimited by and subject to a specific (correlated) time order. The history of time measurement reveals a general awareness of four modes of time: earlier and later, simultaneity, time-flow and irreversibility are well-known modalities of time. In his work on the foundations of physics, Stafleu (1980:16) remarks: 
This is most clearly shown by an analysis of the historical development of time measurement. Initially, time measurement was simply done by counting (days, months, years, etc.). Later on, time was measured by the relative position of the sun or the stars in the sky, with or without the help of instruments like the sundial. In still more advanced cultures, time was measured by utilizing the regular motion of more or less complicated clockworks. Finally, in recent developments time is measured via irreversible processes, for example, in atomic clocks.

What is striking in this whole development is that different time orders are used, the one after the other: the numerical time order of succession, the spatial order of simultaneity, the kinematic time order of constancy and the irreversible physical time order, expressed in the relationship of cause and effect.

Both Vollenhoven (cf. Tol, 1995:99 ff.) and Van Riessen (1970:113, 186) adhere to the view that time implies change. However, the (original) physical meaning of change refers to the meaning of those aspects that are foundational to the physical aspect. In fact change can only be detected on the basis of constancy, and therefore endurance (persistence or constancy) is not only inherent in our awareness of time, for it forms an indispensible condition for change. Constancy and change are on an equal footing, similar to succession and simultaneity. As soon as the meaning of (physical) change is analysed, its dependence upon these three foundational modes of time is evident, because change presupposes (the modal meaning of) constancy, simultaneity and succession.

These distinctions are supported by the account of Paul Lorenzen regarding the four units of measurement used in physics, reflecting the first four modes of explanation: mass, length, duration and charge (cf. Lorenzen, 1976:1 ff.). It is noteworthy to mention that Heisenberg, accepting two universal constants (Einstein's postulate of the velocity of light and Planck's quantum of action), was looking for a third universal constant, namely a universal length. He claims that one has to have at least three units - be they length, time and mass or replaced by length, velocity and mass or even length, velocity and energy (Heisenberg, 1958:165). An analysis of the first four modal aspects would have helped him to realise that four are needed. Clearly these four units of measurement reflect the meaning of the first four aspects of reality, namely number ("mass"), space ("length"), the kinematical aspect ("duration") and the physical aspect ("charge"). Weinert (1998:230) mentions even that usually physicists "distinguish fundamental constants from conventional 
units" - and he then lists the kilogramme (number), ${ }^{9}$ the meter (space), the second (the kinematic) and temperature (the physical) (cf. also Lorenzen, 1989).

Since one or another time order is presupposed in every unit of measurement or any actual measurement, the coming into being of the time order concerned can never be measured - explaining why creation in principle cannot be dated! The order diversity within creation ultimately points at an understanding transcending conceptual knowledge - it can solely be approximated in an idea of creation. 10

\section{Striking shortcomings in the thought of Darwin and his followers}

At the time when Darwin's 1859 work appeared, virtually nothing was known about the complexities of the smallest unit capable of independent life, the cell. However, during the last 60 years various natural scientific disciplines succeeded in unravelling the most astonishing detail in this regard. The stunning complexity of the picture that emerged, caused many biologists to express their wonder and awe $\mathbf{1 1}$ for this microworld and to question the leap of faith present in neo-Darwinian circles regarding the accidental origination of the first living entity.

Both Darwin and neo-Darwinism proceed on the basis of a materialistic understanding of nature. Within the context of the contemporary philosophy of science, materialism is seen as physicalistic:

Physicalism denotes what used to be called materialism, the view that the universe is ultimately an entirely physical system. ... Ultimately there are no phenomena in the universe which

9 The Latin designation of mass during the medieval period was "quantitas materiae" (cf. Maier, 1949:144). The kilogram, in its reference to mass, is specified by assigning a (physical) number to it - and what is assigned is the numerical measure of the physical quantity (i.e. mass) concerned.

10 This epistemological distinction between conceptual knowledge and concept transcending knowledge has important implications for questions of origins.

11 After Francis Collins, a longtime leader of the Human Genome Project, described the relation between DNA, RNA and proteins. He remarks "[T]his brief description only scratches the surface of the elegance of DNA, RNA and protein, which continues to be a source of awe and wonder" (Collins, 2007:104). 
cannot be understood in terms of the concepts of physics. (Klee, 1997:99.) ${ }^{12}$

Within the domain of physics (and the material world) Darwin continued to subscribe to universal (and constant) natural laws, but as soon as living entities enter the scene Darwinists deny any typicality and they do not accept the existence of biotic laws. Darwin does speak of a "general law of nature" (Darwin, 1859a:143) and of "a universal law of nature" (Darwin, 1859a:268; cf. also Darwin, 1859a:143, 147, 427, 445). - but he never speaks of biotical laws of nature - even if biotic phenomena are at stake. For him physical laws (or: natural laws) are sufficient - his underlying physicalism that dominates his entire work On the origin of species (cf. Strauss, 2007).

Biological thinking preceding the Origin of species is embodied, as we mentioned, in the tradition of (a vitalistic and) idealistic morphology - from Aristotle up to neo-vitalism of Driesch and his followers. This orientation was accompanied by the idea of a (supposedly) immaterial vital force (entelechie). Since theory formation always explores certain modes of explanation, the effect of elevating one mode of explanation normally results in a monistic theoretical orientation.

Darwin rather opted for the idea that living entities are intrinsically changeful and subject to chance processes. His eventual acceptance of the principle of uniformitarianism (derived from his acquaintance with Lyell's work in the field of geology), however, continued a feature formally similar to an element of idealistic morphology. Between 1831 and 1836, on his world tour, Darwin discovered animal fossils in South America and discerned similarities with variations of living plants and animals found on the Galapagos Islands. In his 1859 work Darwin developed his view of the (incremental) total process of becoming (change) stretching over millions of years -

12 Note that physicalism over-emphasises the physical mode of explanation. The positivist, Neurath, prefers to speak of the "Vienna Circle for Physicalism" and advances the idea of "the unified language of physicalism" (Neurath, 1959:282, 285). We shall return to the following statement of Van Huyssteen which in principle does not differ from the way in which Klee defined physicalism. Van Huyssteen says that we have to "take very seriously the general conclusions and findings of general cosmology" - "that is that this universe is evolving, that all that is within it has had a common physical origin in time, and that all it contains is in principle explicable by the natural sciences" (Van Huyssteen, 1998:75). 
giving rise (through differentiation or speciation) to the rich variety of species we know today. Adaptation is the mechanism through which living things survive, and Darwin characterises the overall process as controlled by natural selection.

\section{Darwin's nominalism}

In respect of the typical structure of entities, nominalism does not accept any conditioning order (universal structures for), or any orderliness (universal structuredness) of such entities. Every entity is strictly individual. In terms of the distinction between rationalism (reifying what is universal) and irrationalism (reifying what is individual), nominalism surely represents an irrationalistic view in connection with the nature of entities, since every individual entity is completely stripped from its universal orderliness (law-conformity) and conditioning order. This characteristic applies to both moderate nominalism, viz. conceptualism (Locke, Ockham, Leibniz and others), and to extreme nominalism, that rejects all general and abstract ideas and accepts only general names (Berkeley and Brentano).

This irrationalistic side of nominalism, however, does not exhaust its multifaceted nature because universals are fully acknowledged within the human mind, at least as general words in the case of Berkeley's and Brentano's extreme nominalism. This restriction of knowledge to universals is typical of rationalism in the sense defined by us. Therefore, it is possible to see nominalism as being simultaneously rationalistic (in terms of the universals - concepts and words - in one's mind), and irrationalistic (in terms of the strict individuality of entities).

\subsection{The common root of diverging trends in modern philosophy}

This dual nature of nominalism forms the starting point of two diverging philosophical developments in modern philosophy.

- On the one hand, it provided rationalism with the possibility to elevate human reason to the level of the creator of a rational order in reality. This follows from the fact that nominalism in fact transposes the universal side of entities into the human mind. The universal side of entities is, however, nothing but the manifestation of the conditionedness of entities by the relevant universal order for their existence. Consequently, if an entity is stripped of its orderliness (its universal side), it is simultaneously stripped 
of its being subjected to a universal creational order. What is left is factual reality in its unstructured, chaotic individuality and particularity (contingency) (cf. Rauche, 1966:97). Driven by the new motive of logical creation, this very feature of nominalism enabled modern philosophy from Descartes onwards to reconstruct all of reality in terms of natural scientific thought. Only the extreme consequences of this natural science-ideal, cancelling in principle also human freedom, were questioned by Kant. Within the (limited) domain of the science-ideal, however, Kant draws the ultimate rationalistic conclusion of nominalism. Indeed, Kant tries to consolidate and strengthen the preceding natural science-ideal, be it in the restricted form of the rationalistically elevated understanding which (though limited to sensibility in order to save a separate super-sensory domain for the practicalethical freedom of autonomous humanity), is considered to be the a priori (formal) law-giver of nature! Nominalism created a vacuum by leaving factual reality in its individuality unstructured. In order to fill up the lack of determination thus created, Kant introduces human understanding to take hold of this vacant position. To be sure, Kant not merely transposes the universal side of entities into human understanding, since he, in fact, elevates human understanding to the level of the conditioning order for things.

Kant advanced the radical humanistic conclusion: the laws of nature are a priori contained in the subjective understanding of the human being: "the categories are conditions of the possibility of experience, and are therefore valid a priori for all objects of experience" (Kant, 1787-B:161). ${ }^{13}$ Human understanding is thus promoted to become the (a priori) formal law-giver of nature in a universally valid way.

- On the other hand, nominalism provided a starting point for all those trends in modern philosophy which, in an irrationalistic fashion, want to take the unique and contingent character of (mostly designated as: historical) reality serious. This avenue explored by nominalism was followed up by a variety of historicistic designs in modern philosophy, for example from the fourth phase of Fichte's thought up to pragmatism, existentialism, contempo-

13 "Categories are concepts which prescribe laws a priori to appearances, and therefore to nature, the sum of all appearances" (Kant, 1787:163); "Understanding creates its laws (a priori) not out of nature, but prescribes them to nature" (Kant, 1783:320; § 36). 
rary neo-Marxism and postmodernism. If reality is tripped both of its orderliness and of its being subjected to a conditioning universal creational order, it seems to be a "self-evident historicistic truth" that, ultimately, everything is historical and therefore taken up in the dynamic and ever-changing contingent flow of historical events.

At this point we can link up the influence of nominalism with neoDarwinistic evolutionism. The remark of Simpson, namely that plants and animals are not types and do not have types, since everyone of them is unique (Simpson, 1969:8-9), is a fully-fledged nominalistic conviction. The genesis of plants, animals and human beings are taken up in a structureless continuum. Systematic distinctions, exemplified in different taxonomies, are nothing but arbitrary names (nomina) given to an immense number of individually different living entities. The universality implied in these names is a product of our constitutive human understanding without any foundation in the "things outside the mind". Already Charles Darwin adhered explicitly to this view in his Origin of species. 14

Remark:

Contemporary biologists still struggle with the dilemma of continuity and discontinuity. The neo-Darwinian geneticist Coyne, for example, designates a discrete cluster of sexually reproducing organisms as a species. He (Coyne, 2009:184) says:

And at first sight, their existence looks like a problem for evolutionary theory. Evolution is, after all, a continuous process, so how can it produce groups of animals and plants that are discrete and discontinuous, separated from others by gaps in appearance and behavior?

This acknowledgment of discreteness is irreconcilable with the notion of evolutionary continuity - unless one subscribes to the intrinsically antinomic stance of emergence evolutionism. The latter idea fits the spirit of the irrationalistic leg of nominalism, rejecting any

14 In the Penguin edition of the Origin of species Darwin's nominalism is explicit: No one can draw any clear distinction between individual differences and slight varieties; or between more plainly marked varieties and subspecies, and species. ... In short, we shall have to treat species in the same manner as those naturalists treat genera, who admit that genera are merely artificial combinations made up for convenience. This may not be a cheering prospect; but we shall at least be freed from the vain search for the undiscovered and undiscoverable essence of the term species. (Darwin, 1859a:443, 456.) 
structural or typical feature belonging to "reality out there". However, faithful to the inherent inconsistency of nominalism (being rationalistic and irrationalistic at the same time), Coyne, at once, also wants to defend the objective reality of species: "yet we know that species have an objective reality and are not simply arbitrary human constructs" (Coyne, 2009:186). From what is asserted on the previous page, it is clear that in the thought of Coyne primacy is given to the irrationalistic side of nominalism, because it is the continuous process of evolution that produces discrete groups: "For years after publication of The Origin, biologists struggled, and failed, to explain how a continuous process of evolution produces the discrete groups known as species."

Of course the irrationalistic side of this nominalistic legacy in the thought of Darwin contradicts his (rationalistic) acceptance of "universal laws of nature". Earlier we noted that he accepted Leyll's view of invariant natural laws, his uniformitarianism; but at the same time, owing to their tendency towards change, living entities are considered to be without constant structures - an outcome of Darwin's irrationalist (nominalistic) understanding of living entities. Nominalism provides a starting point both for modern historicism (with its emphasis on change) and for Darwin's adherence to a nominalistic view of living entities.

\subsection{Progress and incremental change - the assumed origination of first living entities}

It is indeed a matter of consistently thinking through Darwin's nominalism that Gould (1996), in the light of the fossil record, claims that the basic theory of natural selection offers no statement regarding general progress and therefore does not supply a mechanism in terms of which an overall advance might be expected. Gould (1996: 136) writes:

The problem that spawns this confusion within the Darwinian tradition may be simply stated as a paradox. The basic theory of natural selection offers no statement about general progress, and supplies no mechanism whereby overall advance might be expected. Yet both Western culture and the undeniable facts of a fossil record that started with bacteria alone, and has now exalted us, cry out in unison for a rationale that will place progress into the center of evolutionary theory.

The basic unsolved problem for Darwin and neo-Darwinism is found in the total absence of any theory or experiment that accounts for 
the (assumed) transition from the non-living to the living. Darwin's strong belief in an incremental, continuous process inspired natural scientists already in the first half of the twentieth century to generate a rational account of this assumed transition. Great expectations were derived from what Haldane and Oparin (cf. Oparin, 1953, chapters 4-7:64-195) conjectured (Haldane, already in 1928). It was during this period, the twenties and thirties of the previous century, that the so-called "New synthesis " emerged - with names such as Julian Huxley in 1942 (Evolution: the modern synthesis), R.A. Fisher, Theodosius Dobzhansky, J.B.S. Haldane, Sewall Wright, E.B. Ford, Ernst Mayr, Bernhard Rensch, Sergei Chetverikov, George Gaylord Simpson, and G. Ledyard Stebbins associated with it.

What became known as the Oparin-Haldane hypothesis kept the hope alive that it will indeed soon be possible to reconstruct the origination of the first living entity (cell, bacteria). During the fifties Miller and his colleagues designed some experiments based upon specific assumptions regarding the conditions on earth long ago. In particular it was assumed that the initial atmosphere of the earth was mainly composed of hydrogen, methane, ammonia and water vapor. Oparin believed that carbon "made its first appearance on the Earth's surface not in the oxidized form of carbon dioxide but, on the contrary, in the reduced state, in the form of hydrocarbons" (Oparin, 1953:101-102).

The progress made in our understanding of the molecular and biochemical basis of the living cell from this foundational perspective revealed that living entities can only function on the basis of both DNA and proteins. The complexities involved in the structural composition of both are so immense that it is difficult enough to conjecture that any one of the two originated independently and spontaneously. 15 To complicate matters further it is clear that both had to come into being simultaneously for DNA without proteins cannot function and proteins without DNA cannot come into existence. At one of the international conferences on pre-biotic (a-biotic) "evolution" Orgel and Sulston (1971) reported on their attempt to explain

15 The issue is indeed the "information". The chance of randomly selecting the letters in a specific order (at 5000 flips per second) of one page of the genetic code, is calculated to take ten billion years. Since there are actually 500000 such pages, it will take nothing less than five million billion years to "assemble" all of them in their correct arrangement. (Keep in mind that present-day physicists and astronomers estimate our own universe to be less than fourteen billion years old.) 
the concurrent emergence of DNA and protein. However, their report contains something strange. In the first place they stated: "This approach leads to new difficulties so severe that it has never been carried very far" (Orgel \& Sulston, 1971:91). Then they continue about what they considered to be progress. According to them progress was only made when characteristics are attributed to protein and DNA "which have not been demonstrated experimentally, and which usually seem implausible" (Orgel \& Sulston, 1971:91). Isn't it amazing that what seems to be implausible and has never been demonstrated experimentally are appreciated as progress?

It should therefore not surprise anyone that the imaginative attempts to account for the emergence of the first living entity ran stuck in insurmountable difficulties. Almost three decades later Silver (1998) points out that there is at present "no evidence that the atmosphere was reducing (methane and hydrogen)" and remarks that "the prevalent opinion at the moment is that the Earth's atmosphere, at the time that life emerged, was mainly carbon dioxide and nitrogen" (Silver, 1998:344). The role of methane is also unacceptable in the Oparin-story since it is one of the components of natural gas which is produced by the "effect of millions of years of pressure and heat acting on prehistoric plant material" (Silver, 1998:344). Although the Haldane-Oparin conjecture was kept alive for a considerable time, supported by the mentioned experiments done by Stanley Miller (from Chicago) in 1953, it does not bring us closer to an understanding of the mystery of the genesis of the living cell. 16

In the same year in which Silver articulated his concerns, Orgel had to concede:

The Haldane-Oparin hypothesis is out of fashion. Of the forty or so simple molecules that would be needed to form a primitive cell, the experiment produces two. It is worth bearing in mind that glycine contains only ten atoms and alanine, thirteen. The simplest nucleotide contains thirty atoms. The probability that a given large molecule will be produced by chance from small molecules, by sparks, falls drasticcally as the molecular size increases. It has to be realised that even if heat, radiation, and lightning, on the young Earth, had produced all the amino acids and nucleotides needed for present forms of life, the gap between an aqueous solution of these molecules and a living cell is stupendous. It's a question of organisation: in the absence of a guiding intelligence, present-day scientists are not doing very well. For the moment, let's show the Miller experiment to the side door and see who is next in line in the waiting room. (Silver, 1998:345.) 
There are several tenable theories about the origin of organic material17 on the primitive earth, but in no case is the supporting evidence compelling. Similarly, several alternative scenarios might account for the self-organization of a selfreplicating entity from prebiotic organic material, but all of those that are well formulated are based on hypothetical chemical syntheses that are problematic. (Orgel quoted by Lennox, 2007:125-126.)

Lennox then also quotes an earlier statement made by Klaus Dose:

More than thirty years of experimentation on the origin of life in the fields of chemical and molecular evolution have led to a better perception of the immensity of the problem of the origin of life on earth rather than to its solution. At present all discussions on principal theories and experiments in the field either end in stalemate or in a confession of ignorance. (Lennox, 2007:126.)

Behe (2003b:169-170) also remarks:

Of course, if conditions on the ancient earth actually resembled Miller's unsuccessful attempts, then in reality no amino acids would have been produced. Moreover, joining many amino acids together to form a protein with a useful biological activity is a much more difficult chemical problem than forming amino acids in the first place. The major problem in hooking amino acids together is that, chemically, it involves the removal of a molecule of water for each amino acid joined to the growing protein chain. Conversely, the presence of water strongly inhibits amino acids from forming proteins. Because water is so abundant on the earth, and because amino acids dissolve readily in water, origin-of life researchers have been forced to propose unusual scenarios to get around the water problem.

Mills and his co-authors give an overview over key issues in respect of Origin of life hypotheses. They mention a number of difficulties and distortions. For example, the assumption that the early atmosphere had no oxygen - important for simulation experiments - runs stuck in the fact that "there is no proof that oxygen was absent from that atmosphere" (Mills et al., 2003:209). It occurs that when the formation of proteins from amino acids is contemplated nothing is concern is the "origin" of "organic material". 
mentioned of the fact that amino acids only link when they are heated in the dry state (they do not link spontaneously in an aqueous solution - and the assumption is that the early earth contained a lot of water). Moreover, what these authors do not mention is that some of the linkages produced by the dry state are not found in proteins. What is even more disturbing is that these linkages would "prevent the formation of useful amino acid sequences" (Mills et al., 2003:210).

In the absence of an understanding of the complexity of the microdimensions of living entities, Darwin simply conjectured in a truly speculative fashion, that first living entities accidentally originated and that a similar process generated the eye. 18 In his work on Darwin's Black box, the biochemist Behe questions these assumptions in the light of our current knowledge. Regarding the eye it appears to be a hopeless task to provide an evolutionary explanation for its origination:

Anatomy is, quite simply, irrelevant. So is the fossil record. It does not matter whether the fossil record is consistent with evolutionary theory, any more than it mattered in physics that Newton's theory was consistent with everyday experience. The fossil record has nothing to tell us about, say, whether or how the interactions of 11-cis-retinal with rhodopsin, transducin, and phosphodiesterase could have developed, step by step. (Behe, 2003b:292.)

Those who have respect for scientific modesty may do well to reflect upon a remark made by Haldane in a discussion with Silver (1998: 353):

I had a long conversation with J.B.S. Haldane, which started off with politics and ended with science. When I questioned him about evolution, one of his remarks sparked my interest, and sent me to the library that evening: 'Evolution's not the problem. Life is.' Then he said, 'Oparin and I once had an idea about that, but we'll never know the real answer'.

Clearly, one of the co-founders of the "New synthesis", Haldane, thus underscored that solving the problem of "evolution" is much easier than accounting for the presupposition underlying it - explaining the difficulties regarding the origination of the first living entity.

18 Although these processes are indeed different, their degree complexity is similar. 


\section{Darwin on the fossil record}

In Darwin's thought the nominalistic preoccupation with change and continuity inspired the overall idea that living entities experienced slow alterations over vast periods of time. This assumption, in turn, caused paleontologists to believe that there are not only "numerous, fine, intermediate varieties" to be found, but also to view all fossil findings in advance in terms of incremental change. So-called "phyletic gradualism" embodies the nineteenth-century conception of Darwin, namely that species evolve incrementally at a more or less steady rate. He holds:

Geological research ... yet has done scarcely anything in breaking down the distinction between species, by connecting them together by numerous, fine, intermediate varieties; and this not having been affected, is probably the greatest and most obvious of all the many objections which may be urged against my views (Darwin, 1859a:307). ${ }^{19}$

The absence of intermediate fossil forms, unaltered after more than 100 years, caused sufficient discomfort among neo-Darwinist paleontologists. During the seventies of the previous century dissenting voices among them started to emerge. Gould and Eldredge introduced their idea of punctuated equilibria and at the same time D.B. Kitts wrote a significant article in the neo-Darwinist journal Evolution. The title of this article is: Paleontology and evolutionary theory. In it Kitts points out that the spatial distribution and temporal sequence of organisms with which paleontology works is founded in the ordering principles of geology, and can therefore not be incorporated in any biological theory:

Thus the paleontologist can provide knowledge that cannot be provided by biological principles alone. But he cannot provide us with evolution. We can leave the fossil record free of a theory of evolution. An evolutionist, however, cannot leave the fossil record free of the evolutionary hypothesis. (Kitts, 1974: 466.) 20

In $1859 \mathrm{~b}$ this reads:

What geological research has not revealed, is the former existence of infinitely numerous gradations, as fine as existing varieties, connecting together nearly all existing and extinct species. But this ought not to be expected; yet this has been repeatedly advanced as a most serious objection against my views. (Darwin, 1859b:207.)

20 Also Thomson observes that, in the words of Mills et al., "factual patterns of change over time, particularly as seen in the fossil record, can be studied in the 
He plainly states: "Evolution requires intermediate forms and paleontology does not provide them" (Kitts, 1974:467). 21

The other side of this coin is that the fossil record is not at all dominated by Darwin's preoccupation with change. Rather, as Eldredge (of the American Museum of Natural History), notes, it is a fact that stasis or constancy dominates the "fossil record". 22 Gould points out that stasis is data.

Eldredge and I became so frustrated by the failure of many colleagues to grasp this evident point ... The fossil record may, after all, be 99 percent imperfect, but if you can, nonetheless, sample a species at a large number of horizons well spread over several million years, and if these samples record no net change, with beginning and end points substantially the same, $\ldots$, then a conclusion of stasis rests on the presence of data, not on absence! ... Stasis is data (Gould, 2002:759).

Most species "enter the evolutionary order fully formed and then depart unchanged" (Berlinski, 2003:158). Eldredge adds the remark: "and this destroys the backbone of the most important argument of the modern theory of evolution" (Eldredge as quoted by Van den Beukel, 2006:106). 23

This situation clearly shows that the prejudiced and premature preoccupation by Darwin and his followers with change prevented modern (neo-)Darwinian biology to come to terms with the fact that change always presupposes something constant. The one-sided emphasis on change actually denied constancy its rightful place. What Gould and Eldredge designated as the dominant theme of the fossil record, namely stasis (non-change) highlights another impor-

absence of theories of how these patterns came to be" (quoted in Mills et al., 2003:215).

21 To this he adds the remark: "But most of the gaps are still there a century later and some paleontologists were no longer willing to explain them away geologically." (Kitts, 1974:467.)

22 "Gould and I claimed that stasis (= immutability, stand-still), and not change, is the dominant theme of the fossil record" (quoted by Van den Beukel, 2006:106).

23 Gould (1996:68) quotes Prothero and Shubin, who wrote in connection with the supposed evolution of the horse:

This is contrary to the widely held myth about horse species as gradualistically varying parts of a continuum, with no real distinctions between species. Throughout the history of horses, the species are well-marked and static over millions of years. 
tant viewpoint. On the one hand change presupposes the constancy of conditions (in the sense of a law that determines and delimits those entities subject to it), and on the other those subjects may display, notwithstanding variability within certain boundaries, a relative persistence (constancy or identity). The latter phenomenon is supported by the mentioned dominant theme. 24

Although Darwin was unable to give one single example of ancestral changes of species from the fossil record in 1859, he faithfully articulates the continuity postulate of modern philosophy when he says:

If numerous species, belonging to the same genera or families, have really started into life at once, the fact would be fatal to the theory of evolution through natural selection. For the development by this means of a group of forms, all of which are descended from some one progenitor, must have been an extremely slow process; and the progenitors must have lived long before their modified descendants. (Darwin, 1859a:309.)

Ironically enough this is exactly what happened during the "Cambrian explosion". According to Sterelny the standard (neo-)Darwinian story runs "slap-bang into a nasty fact", namely that most "major animal groups appeared simultaneously", that is, at once, about 530 million years ago.

In the 'Cambrian explosion', we find segmented worms, velvet worms, starfish and their allies, mollusks (snails, squid and their relatives), sponges, bivalves and other shelled animals appearing all at once, with their basic organization, organ systems, and sensory mechanisms already operational. We do not find crude prototypes of, say, starfish or trilobites. Moreover, we do not find common ancestors of these groups. (Sterelny, 2001:8990.)

24 This issue is discussed in more detail in Strauss (2009). We just mention a few significant facts. The Coelacanth that was supposed to have died out 65 million years ago, until it was found off the coast of Madagaskar in 1938 - still was identical to the fossils of 65 million years ago. Scheele mentions sharks that did not change over millions of years. Army ants did not change during 100 million years. Pleisiosaurus exhibits little changes during a period of 135 million years. Sea turtle, 110 million years old, did not change during this period. Blue-green algae (Cyanobacteria) are known as the oldest "living fossils", dated to be 3,5 billion years old, yet "they are essentially identical to the blue-green algae that are still living today". 
After hesitantly starting to explore the importance of mutations for its theoretical stance, neo-Darwinism, the New synthesis, eventually settled for the combined operation of mutation and natural selection. However, since mutations are defective (if Darwin knew anything about mutations he would have realised that they are "injurious") in 99\% plus of its occurrences, 25 combining the neo-Darwinian idea of mutation with Darwin's notion of natural selection results in a straight-forward contradiction. The neo-Darwinian argument is indeed that the majority of mutations that are actually defective, may turn out to be advantageous when "nature selects" them through changing circumstances. Yet Darwin (1859a:131) ascribed a much more severe ("extinctive") power to natural selection:

On the other hand, we may feel sure that any variation in the least degree injurious would be rigidly destroyed. This preservation of favourable individual differences and variations, and the destruction of those which are injurious, I have called Natural selection, or the Survival of the fittest. Variations neither useful nor injurious would not be affected by natural selection, and would be left either a fluctuating element, as perhaps we see in certain polymorphic species, or would ultimately become fixed, owing to the nature of the organism and the nature of the conditions.

What neo-Darwinism appreciates as a turn-around, that is, changing devolution into evolution, in terms of Darwin's position would have achieved to opposite outcome: "... any variation in the least degree injurious would be rigidly destroyed"! This means that the neoDarwinian view of what is injurious (the majority of mutations) flatly contradicts Darwin's own understanding of the relation between what is "in the least degree injurious" and the effect of natural selection upon it ("rigidly destroying it").

\section{The uniqueness of humankind}

Although the continuity postulate of the modern humanistic science ideal largely dominated modern thought up to the nineteenth century, the problem of discontinuity and irreducibility constantly made itself felt in various disciplines. Modern physics, for example, in its mechanistic main tendency, adhered to a functionalistic understanding of the universe which was assumed to be both continuous

25 Dobzhansky (1967:41) explains: "Mutation alone, uncontrolled by natural selection, could only result in degeneration, decay, and extinction." 
and infinitely divisible. However, with the discovery of the discrete quantum of energy by Max Planck it turned out, as we have observed earlier, that physical space is neither continuous nor infinitely divisible. Konrad Lorenz is therefore justified in his sharp rejection of the mechanistic postulate of continuity:

From events in the atom to those in the history of humanity inorganic as well as organic developments occur in leaps. Even though some quantitatively summarized processes in this course of events might superficially appear continuous, eventually it turns out to be as discontinuous as the major qualitative changes in organic evolution, first clearly understood by Hegel. (Lorenz, 1973:186.)

Although the neo-Darwinian synthetic evolutionary theory in principle chooses for a physical basic denominator, efforts are nonetheless made to account for the qualitative differences which supposedly emerged in the course of the continual evolutionary process. J. Huxley warns against the "nothing but" trap into which many evolutionary and natural scientific explanatory techniques fall:

... if sexual impulse is at the base of love, then love is regarded as nothing but sex; if it can be shown that man originated from an animal, then in all essentials he is nothing but an animal. This, I repeat, is a dangerous fallacy. We have tended to misunderstand the nature of the difference between ourselves and animals. We have a way of thinking that if there is a continuity in time there must be a continuity in quality. (Huxley, 1968:137.)

Simpson (1969:8) also distinguishes between non-biotic and biotic levels (of organisation) and is convinced that it is preposterous "to base ... a concept of scientific explanation wholly on the nonbiological levels of the hierarchy and then to attempt to apply it to the biological levels without modification". Any treatment of this problem would, according to Simpson (1969:21) have to avoid the extremes of both vitalism and "physicism". Against an extreme physicalist reductionism he (Simpson, 1969:26) openly states: "I think it fair to say that in this respect, as truly biological investigation and an attempt to explain vital phenomena, unmodified reductionism has failed." Because of this he remains convinced that evolutionary organismal biology cannot be reduced "to a philosophy taking account only of the physical, non-biological aspects of the universe" (Simpson, 1969:7). Simpson rejects an extreme reductionism (physicalism), and speaks of the physical and biological aspects of reality. Does this mean that with this distinction he implies an irreducibility in principle between the physical and biotical aspects? Appa- 
rently not, since when he says that the principles of evolutionary biology (which otherwise do not contradict anything in physics) transcend the principles which can be deduced from non-living atoms and molecules, he still adds: "... but without becoming anything other than naturalistic" (Simpson, 1969:7). Only the concept of organisation in the end indicates in which respects living and nonliving things differ: "It is the complexity and the kind of structural and functional assembly in living organisms that differentiate them from non-living systems" (Simpson, 1969:7). In Simpson's view the biotical aspect emerges out of the organisational complexity of natural systems, which actually implies that the term biotical aspect cannot be understood in the sense of an irreducible ontic mode. Although not stated in extreme reductionistic, or unmodified reductionistic terms, Simpson (1971) still defends a form of physicalism, albeit a physicalism in which it appears as if the differences among various levels of organisation are taken into account.

Against this background, Simpson (1971:271) says the following about the human being:

Man has certain basic diagnostic features which set him off most sharply from any other animal and which have involved other developments not only increasing this sharp distinction but also making it an absolute difference in kind and not only a relative difference of degree.

These are pretty strong words - "an absolute difference in kind". 26

It appears that a basic element in this picture is the difference between the sensitive intelligence of animals and the rational intelligence of human beings. Only in the latter case do we discern a normed accountability - something completely lacking in animals. In the absence of acknowledging the normativity of human life, experiments with animals (in respect of their alleged thinking and lingual capacities) therefore never investigated instances of, for example, illogical behavior. Chimpanzees unsuccessfully struggled for nine months to copy a square and a circle (in Munster, Germany). How

26 A more extensive account of the distinctive human functioning within the logicalanalytical, cultural-historical and lingual aspects of reality is found in Strauss (2009; Chapter 4). 
then will one be able to show that they can form an illogical concept, such as that of a square circle? 27

Likewise neo-Darwinism considers animals to be capable not only of the use of tools, but also of making them. However, the archaeologist Narr points out that the presence of a person's inventive, formative, imagination provides the foundation for practically useful archaeological criteria in terms of which typically human tools can be distinguished.

- The form of the produced tool might not be suggested or determined by the original raw material (e.g. in distinction from a stick from which irritating leaves and twigs need merely be removed).

- The function of the tools might not be suggested (a rock in its natural shape is a strengthening of the fist; a stick an elongation of the arm or fingers), that is, tools may not be merely extended bodily organs.

- The manner of production might not be suggested, with appeal to the technical moment that implies that tools must be formed by means of (formed or unformed) tools (cf. Narr, 1974:105; 1976: 99-101). 28

In addition to the unique human functioning within the logicalanalytical and cultural historical aspects of reality their function within the sign mode also highlights the distinctness of being human. It is interesting to note that at birth the human larynx is positioned in exactly the same way as that of all other mammals. One reason for this is that the human infant needs a way for milk intake that is separate from the windpipe. The baby can breathe calmly while drinking. Exactly because of this the human infant is incapable of speech - like all mammals. Only by means of the gradual removal of this division, caused by the downward movement of the larynx freeing the larger pharynx cavity - is the human person eventually enabled to speak. Only human beings possess an intermediate area between the nasal cavity and the larynx where air and food channels example of an illogical concept. Yet this example is actually already found in Immanuel Kant's Prolegomena zu einer jeden künftigen Metaphysik die als Wissenschaft wird auftreten können (Kant, 1783:341; § 52b). 
cross (Laitman, 1985:282). If we define a speech organ as that bodily part which exists solely in service of the production of speech sounds, then a surprising fact is that there are no human speech organs. Let us enumerate possible candidates: the lungs, larynx, mouth cavity, palate, teeth, lips and nose cavity. Without exception, all these organs perform primary functions that would continue to function in their normal way even if human beings never uttered a single word (Overhage, 1972:243). Human language simply takes hold of all these different organs in the production of speech sounds.

This highly developed and subtle cooperation, especially of three organs so heterogeneous in character as the mouth, the larynx and the brain, integrated in the production of human speech sounds, makes it rather difficult, if not hopeless, to provide us with a causal evolutionistic explanation of this astonishing phenomenon. The question arises what number of miraculous changes should have occurred to produce the articulation conditions necessary for truly human language formation.

\section{Inconsistencies in the attempted synthesis between neo-Darwinism and Christianity}

Since theoretical thinking is characterised by modal abstraction every academic discipline ultimately operates on the basis of a theoretical view of reality in which (implicitly or explicitly) an account is given of the diversity of (modal) aspects of reality. Neither the discipline of physics nor that of biology has succeeded to escape from the presence of such an all-pervasive theoretical view of reality. The story of the concept of matter within the development of physics displays the successive exploration of the first four modal aspects of reality (cf. Strauss, 2009:402-416). The theoretical view of reality of the Pythagoreans advanced the overall perspective that everything is number. After the discovery of irrational numbers (cf. Von Fritz, 1945) - revealing within the seemingly form-giving and delimiting function of number something formless - Greek mathematics as a whole was transformed into a spatial mode (the geometrisation after the initial arithmetisation). As a consequence, material entities were no longer described purely in arithmetical terms. The aspect of space now provided the necessary terms required to characterise material entities. This spatial angle of approach remained in force until the rise of modern philosophy, since philosophers like Descartes and Kant still saw the essence of material things in their extension. Particularly through the work of Galileo and Newton, the main tendency of classical physics eventually underwent a shift in 
perspective by attempting to describe all physical phenomena exclusively in terms of (kinematic) motion. Beginning with the introduction of the theory of the atom by Niels Bohr in 1913, and actually already from the discovery of radio-activity in $\mathbf{1 8 9 6}$ and the discovery of the energy quantum $h$, modern physics realised that matter is indeed characterised by physical energy-operation.

From this brief explanation, it is clear that different aspects served to characterise matter by reducing it to one of the four most basic modes of explanation of reality - starting with the perspective of number and then proceeding to the aspect of space, the kinematic aspect and eventually the physical aspect of reality.

The history of biology, as we have noted above, displays a similar plethora of reductionistic orientations that explored different modes of explanation, alternatively elevating certain modal aspects to serve as exclusive modes of explanation. Just recall the mechanistic orientation (Eisenstein), the physicalistic approach (neo-Darwinism), neovitalism (Driesch, Sinnott, Schubert-Soldern, Haas and Heitler), holism (Adolf Meyer-Abich), emergence evolutionism (Lloyd-Morgan, Woltereck, Bavink, Polanyi), the organismic biology of Von Bertalanffy, and panpsychism (Teilhard de Chardin, Bernard Rensch), complexity theory (Behe) and the idea of "intelligent design". 29

Owing to the irreducibility of the various modes of explanation these different ismic orientations (schools of thought) are mutually exclusive. Neo-Darwinism, for example, with its emphasis on the randomness of the combined effect of natural selection and mutation, does not allow for any form of teleology or purpusiveness (goaldirectedness) and therefore contradicts the basic orientation of the (neo-)vitalist, organismic and holistic trends of thought. Pan-psychism, by contrast, opts for another basic denominator (mode of explanation). Rensch (1971:159) characterises his own position as "panpsychistic" and "identistic" - that is, all events are founded by something which is neither psychic nor material, but which has psychic and material characteristics. Within the context of the primacy of the modern humanistic science ideal with its levelling continuity

29 It is surprising that Michael Behe who is so critical of neo-Darwinism still falls into a physicalistic mode of speech when he refers to "molecular life" (Behe, 2003a:5). Just like Darwin, Behe and other intelligent design theorists also do not acknowledge genuine biotic laws - see the penetrating analysis and critique of Zylstra (2004). 
postulate, it implies that the evolutionary continuum is considered in terms of a psychic basic denominator. If no discontinuities exist in the evolutionary line of descent, then lower animals, plants, and even the inorganic sphere should exhibit certain corresponding "psychic" components - a consequence indeed drawn by Rensch (1959:352): "According to our previous findings and discussions we are justified in assuming ... psychic (parallel) processes of some kind in all living beings". This "psychic" continuity also bridges the transition from living to non-living:

Here again it is difficult to assume a sudden origin of first psychic elements somewhere in this gradual ascent from nonliving to living systems. It would not be impossible to ascribe 'psychic' components to the realm of inorganic systems also, i.e. to credit nonliving matter with some basic and isolated kind of 'parallel' processes. (Rensch, 1959:352.)

Rensch therefore believes that such a panpsychistic approach has the advantage of not having to assume that the psychic, as something basically distinctive from the material, appeared on our planet at some stage after the emergence of living creatures. As a substitute for the assumption that psychic phenomena appeared suddenly after an astronomic and geological prehistory of millennia, Rensch (1969:134-135) considers it far more conceivable and acceptable to link the evolution of the psychic to the evolution of the material (anzufügen), that is to ascribe a protopsychic nature to matter.

Without questioning the continuity postulate it is alternatively possible to adhere to the primacy of the humanistic - in which case freedom has to be projected back to the level of atomic and molecular interaction. H. Jonas is "forced", in the interest of the primacy of the freedom ideal, to recover freedom on the level of the material. "Our position is in actual fact that it is possible to observe freedom already at the level of metabolism - yes, even that it is the first form of freedom." (Jonas, 1973:13.) His indebtedness to the dialectical humanistic ground motive of nature and freedom is clear, for according to him "life manifests this polarity in a durable fashion in the fundamental antithesis within which its existence weaves itself: the antithesis of existence and non-existence, of self and world, of form and matter, of freedom and necessity" (Jonas, 1973: 15-16).

In line with Huxley's rejection of the "nothing but" fallacy and Simpson's emphasis on an absolute diference in kind the neo-Darwinian 
geneticist, Thoedosius Dobzhansky, acknowledged typical laws for different levels - thus approximating the idea of sphere-sovereighty initiated by Groen van Prinsterer and Abraham Kuyper and expanded by Dooyeweerd in an ontological sense. Dobzhansky (1967:43) writes:

The phenomena of the inorganic, organic and human levels are subject to different laws peculiar to those levels. It is unnecessary to assume any intrinsic irreducibility of these laws, but unprofitable to describe the phenomena of an overlying level in terms of those of the underlying ones.

Whereas someone like Richard Dawkins claims that "Darwin made it possible to be an intellectually fulfilled atheist" (Dawkins, 1986:6), many Christians allege that God "created through evolution". Of course the question is what kind of evolution is intended? Did God "use" the neo-Darwinian model of random mutation and natural selection, or the neo-vitalist conviction that living things are constituted by physical matter and by an "immaterial vital force" (Haas,1974), 30 or one or another emergent-evolutionistic process (with continuity in descent and discontinuity in existence), or the typo-strophism theory of Schindewolf $(1969 ; 1980)$, or perhaps the idea of punctuated equilibria advanced by Gould? These questions, that can be multiplied, relate to the underlying philosophical problems of universality and what is individual as well as to the foundational position of constancy in respect of change. In particular they are also connected to the difficulty that the mentioned ismic standpoints within modern biology each represent the deification (absolutisation) of a different aspect within creation, substituting God as creator. These orientations are not only mutually exclusive for they also contradict the Biblical distinction between God and (the various aspects of) creation.

The attempted synthesis between Christianity (sometimes identified with theology) and "evolution" in practice normally terminates in a position where the physicalist orientation of Darwin and neoDarwinism serves as a point of departure, but along the line the closer one gets to a Biblical perspective, gets transformed into a (neo-)vitalistic and/or emergent-evolutionistic orientation. An example of this line of development is found in the writings of Van Huysproduce a non-material bearer of life plans." (Haas, 1974:355.) 
steen. They demonstrate a strange mixture of different positions at once. On the one hand he claims that our universe "and that all it contains is in principle explicable by the natural sciences" (Van Huyssteen, 1998:75) and on the other he warns that we should not overextend rationality "to explain everything in our world in the name of natural science" (Van Huyssteen, 1998:115). He commences by subscribing to the neo-Darwinian presupposition of continuity and chance (cf. Van Huyssteen, 1998:111) and then subtly reverts to a view that is a mixture of emergent evolutionism and vitalism (cf. Van Huyssteen, 1998:37, 121, 125, 127, 134, and 151). He does not realise that these orientations contradict the basic assumptions of neoDarwinism.

In his more recent work, Alone in the world? Van Huyssteen (2006) continues to accept the continuity between species in respect of instincts or rational abilities as well as the continuity of organic evolution from "unicellular organisms to humans" (Van Huyssteen, 2006:81, 86-87). Just as in the case of his 1998 work he discerns something unique within human cognition, culture and religious worldviews, and even characterises these facets as something irreducible. He believes that within the "grandiose universal natural history" once cultural evolution commenced it "obeyed its own principles". This is quite similar to the quoted position of Dobzhansky - concerning different laws peculiar to different levels. Yet, while Dobzhansky rejects the idea of irreducibility, Van Huyssteen defends it, for according to him culture is not reducible to biological entities (Van Huyssteen, 2006:78). While distinguishing between laws of nature (Van Huyssteen, 2006:55) and cultural evolution with its "own principles", as well as alluding to "particular modes of explanation" (Van Huyssteen, 2006:98), one may ask what the origin of these (irreducible) laws and principles are? Since laws condition (in the sense of making possible) what is subjected to them these laws cannot originate in a process presupposing them. Likewise, if there are "own principles" for culture, these principles, making possible cultural activities, cannot originate in cultural processes.

Given his 1998 position, where it was claimed that the universe and "all it contains is in principle explicable by the natural sciences", we once more read the opposite in 2006. With affirmation Van Huyssteen quotes the "evolutionary epistemologist" O'Hear who says:

For religious believers it will be natural to interpret the emergence of consciousness and self-consciousness as revelatory of something deep in the universe, something inex- 
plicable by physics, something behind the material face of the world. (Van Huyssteen, 2006:97.)

Yet, while leaving the house of deterministic neo-Darwinian evolutionism through the front door, the back door also received a last brief visit: "But for evolutionary epistemology to be truly nonreductionistic and nondeterministic, we should take seriously the argument, made even by Wuketits, that we humans are in a sense genetically disposed to religious and metaphysical beliefs" (Van Huyssteen, 2006:99; cf. Wuketits, 1990:155, 199). If we are "genetically disposed to religious and metaphysical beliefs" we still believe that the "natural sciences" (in this case biology-genetics) can explain everything.

\section{Theoretical problems facing emergent-evolutionism}

Material entities have their highest active (i.e. subject) function within the physical aspect of reality. The idea of emergent properties may suggest that increasing complexity can produce, from a mere physical constellation, the biotic aspect of reality. Alternatively it can assume that an additional subject function can "emerge", namely the biotic aspect (as Klapwijk argues - cf. Klapwijk, 2008). Can a particular function change into another function? Just consider the conviction that physical entities were transformed into biotic (i.e. living entities).

The problem here is a quite serious theoretical issue, for if we accept that the physical function can change (be "transformed") into the biotic aspect, the next problem is if there will still exist a physical aspect of reality after the change of the physical into the biotical? This seems to be impossible if the physical aspect turned into the biotical aspect. A less rigorous version may contemplate the question whether or not it is possible for one aspect to give rise ("birth") to the existence of another aspect? For in this case the continued existence of the initial aspect may be maintained. Yet, if this transition does not eliminate the initial (or primary) aspect, it is incorrect to claim that it changed into a different aspect. While holding on to the idea of transformation the only other option seems to be to defend some or other view of emergence in terms of which it is claimed that an on-going process eventually gives rise to various new aspects of reality. It is often asserted that once these additional aspects emerged (came into existence) they are irreducible. Emergent evolutionists (such as defended by Lloyd-Morgan, Whitehead, Alexander, Woltereck, Bavinck and Polanyi) indeed want to have it both ways: continuity in descent (in the process of origination) and dis- 
continuity in existence (in structure). Structure thus becomes the product of the genetic process of becoming. 31 It seems as if some attempts at establishing a synthesis between Christianity and evolution gets entangled in these intrinsic antinomies present in the thought of emergent-evolutionistic thinkers.

\section{Ultimate commitments}

We mentioned the argument of Clouser that a religious belief is "a belief in something as divine per se no matter how that is further described, where 'divine per se' means having unconditionally nondependent reality" (Clouser, 2005:23). He takes philosophical materialism as an example, the view "that reality is ultimately physical, so that everything is either matter or dependent on matter" (Clouser, 2005:35). He does not deny the differences between theory and religion, but argues that no single academic discipline can avoid the directing and guiding influence of one or another religious belief in the sense just defined. His example of materialism fits neoDarwinism completely - the latter is the outcome of a specific (materialistic) presupposition. Some contemporary biologists even go further. Lynn Margulis, from Massachusetts University, who is known for her theory regarding the nature of mitochondria (a subcellular organ that probably previously was an independent bacterium), for example, remarked that ultimately history will see neo-Darwinism as a "minor twentieth-century religious sect within the sprawling religious persuasion of Anglo-Saxon biology" (Behe, 2003a:26). That atheism is a faith-conviction that is defended by the immunologist, George Klein, who holds that his "atheism is not based on science, but is an a priori faith commitment". In response to the accusation that he is an agnostic, Klein says:

I am not an agnostic. I am an atheist. My attitude is not based on science, but rather on faith ... The absence of a Creator, the

31 Emergence evolutionists openly admit that their position is burdened by an inner antinomy. Richard Woltereck does so in his Ontologie des Lebendigen (1940:300 ff.), while Michael Polanyi (1968:393) writes:

We have reached the point at which we must confront the unspecifiability of higher levels in terms of particulars belonging to lower levels, with the fact that the higher levels have in fact come into existence spontaneously from elements of these lower levels. How can the emergent have arisen from particulars that cannot constitute it. 
non-existence of God is my childhood faith, my adult belief, unshakable and holy (Klein, 1990:203; cf, Lennox, 2007:34). ${ }^{32}$

The embarrassment with constancy as dominant pattern of the fossil record caused Gould to take refuge in the allopatric theory according to which at "another place" "new species arise in very small populations that become isolated from their parental group at the periphery of the ancestral range". This gives rise to "speciation in these small isolates" that occurred in a way that is "very rapid by evolutionary standards" (Gould, 1992:61). Without any factual support, this speculative claim serves to avoid the said embarrassment with the "sudden appearance of species in the fossil record and our failure to note subsequent evolutionary change within them" (Gould, 1992:61). This assumption of Gould is similar to the embarrassment with the origination of the first living entity. Wilhelm Troll (1973:8-9) categorically states, in his standard text book on botany, that the question concerning the origination of life on earth, owing to its speculative nature, does not belong to the domain of biology as an empirical science.

Yet, in spite of the absence of the "intermediate forms" (required by evolution and not provided by paleontology - Kitts) and the dominant constancy of fossil forms over millions of years (Gould and Eldredge) neo-Darwinism religiously upholds their belief in the continuous transition of all forms of "life". Their ultimate commitment appears to override the factual evidence and to eliminate the required scientific modesty exemplified in a sincere docta ignorantia (learned ignorance).

\section{Appendix}

\section{A summary critique of the pretentions of neo-Darwinism}

Some of the key claims of neo-Darwinism are (most of them touched upon in die preceding article):

1. It is an objective and neutral theory that is not influenced by any philosophical or religiuous presuppositions.

2. It is a purely special scientific (i.e. biological) theory.

32 Other important perspectives that exceed the brief analysis of this presentation are more extensively treated in Strauss (2009; Chapters 4 and 7). 
3. It is a purely natural scientific theory.

4. It is sufficiently supported by factual data.

Are these claims justified?

\section{Is biology objective and neutral?}

- The mere existence of diverging trends of thought contradicts the claim to neutrality.

- Neo-Darwinism in particular departs from an accepted faith in the "creative power" of the combination of mutation and natural selection, that is, from an assumed purely accidental process. The term evolution is endowed with the power of an origin. It replaces the Biblical creational faith within living nature, where it is assigned with the capacity to serve as the foundation of the total diversity of forms of life.

\section{Is neo-Darwinism a purely scientific theory?}

Neo-Darwinism is not purely special scientific in nature, because it tells a story embracing the universe in all respects. It starts with elementary particles, atoms, molecules and macromolecules and it ends with humankind - the result of a meaningless material process, the accidentally most intelligent animal, humankind was not foreseen (Simpson). The focus on the totality of our experiential world disqualifies neo-Darwinism to be a special scientific theory - it is a full-grown philosophical theory regarding the becoming of the entire universe.

\section{Is it a purely natural scientific theory?}

The spiritual background of neo-Darwinism reflects diverse perspectives that are not derived from the natural sciences.

- Its emphasis on change derives from the rise of historicism at the beginning of the nineteenth century. This historicism inspired Darwin's preoccupation with change - at the cost of constancy.

- Darwin's idea of a "struggle for existence" goes back to Hobbes who portrayed the assumed (hypothetical and not historical) "state of nature" as a battle of everyone against everyone (bellum omnium contra omnes). Combined with a writing from Malthus, An essay on the principle of population and its effects of the future improvement of society (1798), this inspired Darwin to 
develop his idea of the "struggle for existence" (the expression "surival of the fittest" was proposed by Spencer). 33

The contemporary social-political thinker, Kropotkin (1842-1921), already in 1903 pointed out that Darwin presented a skewed image of nature to us for it ignores the fact that next to struggle phenomena there are also numerous examples of peaceful and harmonic co-existence (symbiosis). This once more highlights the influence of social philosophic conceptions on the thought of Darwin. 34

- The whole idea of selection is also highly problematic. Darwin explicitly states that he derives it from the human ability to choose (select), and that as a result he employs it in a metaphorical sense: "I have called this principle, by which each slight variation, if useful, is preserved, by the term of Natural Selection, in order to mark its relation to man's power of selection" (Darwin, 1968:115). McGrath (1999) correctly observes that Darwin makes an appeal to a conscious process of selection: "The analogy is apparently being allowed to imply that the active selection of the animal or plant breeder is somehow paralleled within nature itself. This is certainly suggested by his frequent references to 'nature' as an agent who actively 'selects' variants which she approves as good" (McGrath, 1999:172). Alfred Russell Wallace indeed wrote to Darwin that this analogy is misleading: "I am led to conclude that the term itself, and your mode of illustrating it, however clear and beautiful to many of us, are not yet the best to impress it on the general naturalist public" (cf. McGrath, 1999:172).

- Of course the assumed (accidental) origination of the first living entities on earth cannot be explained in terms of natural selection, because the operation of the latter presupposes living entities already in existence. 35

33 However, Sober remarks that "the degree to which Malthus changed the direction of Darwin's thought remains controversial" (Sober, 1987:15).

34 Gould argues that Darwin's accidental story does not provide any grounds for the idea of progress, although he advances this progress idea through the back door of a complex and dubious ecological argument. Gould (1996:143-144) writes: "He provided no clear rationale for biotic predominance - and Kropotkin and other critics would nail him on this point later."

35 Von Bertalanffy (1973:160-161) remarks: "In contrast to this it should be pointed out that selection, competition and 'survival of the fittest' already presuppose the 


\section{Is it sufficiently supported by factual data?}

The first living entity cannot be accounted for, the simultaneous appearence of the main groups of animals during the Cambrian explosion contradicts Darwin's expectation of gradual incremental succession, 36 while the fact that most species "enter the evolutionary order fully formed and then depart unchanged" (Berlinski, 2003: 158) even caused Eldredge to add the remark that "this destroys the backbone of the most important argument of the modern theory of evolution" (quoted in Van den Beukel, 2006:106). ${ }^{37}$

Widely known and popular arguments and facts found in many textbooks and popular accounts of evolution turned out to lack factual support. Gould referred to the just quoted "widely held myth about horse species as gradualistically varying parts of a continuum". Behe ridiculed the absence of any sound account of the origination of the first living entity or complex organs - just compare it with what Darwin said: "If it could be demonstrated that any complex organ existed, which could not possibly have been formed by numerous, successive, slight modifications, my theory would absolutely break down" (Darwin, 1859a:219). We mentioned that Darwin's view of natural selection, according to which injurious variations "would be rigidly destroyed", cannot be reconciled with mutations that are in more than 99\% instances "injurious". The embryos of Haeckel turned out to be fraudulent (Wells, 2003:180 ff.); the story of peppered moths collapsed because "textbook pictures of peppered moths ... show specimens that have been manually placed on tree trunks" (Wells, 2003:190); almost all of dozens of so-called "vestigal

existence of self-maintaining systems; they therefore cannot be the result of selection". With reference to Meyer and Weber, Depew (2003:447-448) more recently writes that "... natural selection cannot in principle be the cause of life's origin. Natural selection is a phenomenon that depends on the very sort of variation and heredity that exists in organisms and so can hardly be used to explain how organisms came into existence in the first place".

36 "Geological research ... yet has done scarcely anything in breaking down the distinction between species, by connecting them together by numerous, fine, intermediate varieties; and this not having been affected, is probably the greatest and most obvious of all the many objections which may be urged against my views" (Darwin, 1859a:307).

37 We mentioned that Gould quoted Prothero and Shubin, who wrote, in connection with the supposed evolution of the horse:

This is contrary to the widely held myth about horse species as gradualistically varying parts of a continuum, with no real distinctions between species. Throughout the history of horses, the species are well-marked and static over millions of years (cf. Gould, 1996:68). 
organs" in the course of time appeared to have a useful function (cf. Mills et al., 2003:215 ff.). 38

Additional Remark on Australopithecus sediba (made public in April 2010) while checking the final proofs received from Koers:

In newspapers, Carte Blanche (April 11) and the TV program 50/50 (April 12) Australopithecus sediba is presented as the "missing link" and the direct ancestor of modern humans (Homo sapiens). The unbridled enthusiasm accompanying this discovery appears to confuse two distinct issues:

- the well-preserved nature of this fossil compared to other Australopithecines fossils, such as Australopithecus afarensis ("Lucy") and Australopithecus robustus; and

- the relationship between the Australopithecines and modern humans. The logic of popular statements suggests that these wellpreserved fossils promoted them suddenly to become true ancestors of modern humans.

The web page on Australopithecus sediba has a heading saying "Ancient skeleton may shed light on human evolution": http://www.aolnews.com/article/scientists-to-unveil-possible-missinglink-between-man-and-ape/19425931

Another remark makes it clear that Australopithecus sediba is not an ancestor of modern humans for it merely may shed light on the (assumed!) transition between the extinct apelike ancestors of modern humans: "The fossil could provide new clues about the transition between the human species and its extinct, apelike ancestors." 39

Another suggestion arising from this new finding is that the link may be via Homo habilis. When skull 1470 was made known in 1973 its estimated age was 2,8 million years - soon brought down to 2 million years. It does not have the prominent eyebrows of the Australopithecines or Homo erectus forms, a relatively larger brain

38 Additional perspectives on the uniqueness of the human being are found in the mentioned Chapter four of Strauss (2009).

39 The Australopithecines lived between 5 and 1 million years ago - and Gould highlights the fact that the best documented Australopithecines recorded stasis of 0,8 to 1,0 million years (Gould, 2002:834). 
capacity and a more Homo sapiens-like appearance compared with the Australopithecines. Yet, on the basis of investigating the balance organ of Homo habilis Homo habilis type never walked upright. What is merely suggested by the labyrinth is that Homo habilis was not more and also not less bipedal than the Australopithecines. Its structure looks like that of gibbons or apes, but in any case is not human (De Burgh, 1995:21 - for more detail cf. Strauss, 2009:115117).

\section{List of references}

BAVINK, B. 1954: Ergebnisse und Probleme der Naturwissenschaften, Zürich: Hirzel.

BEHE, M.J. 2003a. Design in the details: the origin of biomolecular machines. (In Campbell, J.A. \& Meyer, S.C. Darwinism, design, and public education. East Lansing: Michigan State University Press. p. 287-302.)

BEHE, M.J. 2003b. Darwin's black box: the biochemical challenge to evolution. New York: Free Press.

BERLINSKI, D. 2003. The deniable Darwin. (In Campbell, J.A. \& Meyer, S.C. Darwinism, design, and public education. East Lansing: Michigan State University Press. p. 157-177.)

CASSIRER, E. 1969 [1910]. Substanzbegriff und Funktionsbegriff. Darmstadt: Wissenschaftliche Buchgesellschaft.

CLOUSER, R.A. 2005. The myth of religious neutrality: an essay on the hidden role of religious belief in theories. New revised ed. Notre Dame: University of Notre Dame Press.

COLLINS, F. 2007. The language of God. New York: Simon \& Schuster.

COYNE, J.A. 2009. Why evolution is true. Oxford: Oxford University Press.

DACQUÉ, E. 1935. Organische morphologie and phylogenie. Berlin: De Gruyter.

DACQUÉ, E. 1940. Die Urgestalt. Leipzig: Im Insel.

DACQUÉ, E. 1948. Vermächtnis der Urzeit. München: Leibniz.

DARWIN, C. $1859 \mathrm{~b}$. On the origin of species by means of natural selection or the preservation of favoured races in the struggle for life. http://www.infidels.org/library/historical/charles_darwin/origin_of_species/l ntro.html Date of access: 29 Oct. 2005.

DARWIN, C. 1968 [1859a]. On the origin of species by means of natural selection or the preservation of favoured races in the struggle for life. Ed. with an introduction by J.W. Burrow. Hardmondsworth: Penguin Books. (The version available on the WEB (see Darwin, 1859b) slightly differs in some respects from the Penguin edition.)

DAWKINS, R. 1986. The blind watchmaker: why the evidence of evolution reveals a universe without design. New York: Norton.

DEKKER, C., MEESTER, R. \& VAN WOUDENBERG, R. 2006. Schitterend ongeluk of sporen van ontwerp? Kampen: Ten Have.

DEPEW, D. 2003. Intelligent design and irreducible complexity: a rejoinder. (In Campbell, J.A. \& Meyer, S.C. Darwinism, design, and public education. East Lansing: Michigan State University Press. p. 441-454.) 
DOBZHANSKY, Th. 1967. The biology of ultimate concern. New York: New American Library.

DRIESCH, H. 1929. The science and philosophy of the organism. 2nd ed. London: Black.

DUYVENÉ DE WIT, J.J. 1962. Evolution as Christocentrically directed process. (In De Chardin, Teilhard. Christian perspective. Hamilton: Guardian Publishing. p. 53-70.)

EISENSTEIN, I. 1975a. Ist die Evolutionstheorie wissenschaftlich begründet? Philosophia naturalis: Archiv für Naturphilosophie und die philosophischen Grenzgebiete der exakten Wissenschaften und Wissenschaftsgeschichte, 15(3):Teil 1.

EISENSTEIN, I. 1975b. Ist die Evolutionstheorie wissenschaftlich begründet? Philosophia Naturalis: Archiv für Naturphilosophie und die philosophischen Grenzgebiete der exakten Wissenschaften und Wissenschaftsgeschichte, 15(3):Teil 2.

GENTRY, R.V. 2001. Flaws in the big bang. arXiv:physics/0102096. http://www.orionfdn.org/papers/arxiv-5.pdf Date of access: 28 Sept. 2009.

GOULD, S.J. 1992. Reflections in natural history: ever since Darwin. New York: Norton.

GOULD, S.J. 1996. Life's grandeur. London: Vintage.

GOULD, S.J. 2002. The structure of evolutionary theory. Cambridge: Harvard University Press.

HAAS, J. 1959. Naturphilosophische Betrachtungen zur Finalität und Abstammungslehre. (In Haas, A. Die stammesgeschichtliche Werden der Organismen und des Menschen. Vol. 1. Basel: Herder. S. 453-514.)

HAAS, J. 1968. Sein und Leben: Ontologie des organischen Lebens. Karlsruhe: Badenia.

HAAS, J. 1974. Das organische Leben. (In Huttenbugel, J., ed. Gott, Mensch, Universum. Graz: Styria. S. 325-356.)

HEISENBERG, W. 1958. Physics and philosophy: the revolution in modern science. New York: Harper Torchbooks.

HEITLER, W. 1976. Ueber die Komplementarität von Lebloser und lebender Materie. Abhandlungen der mathematisch-naturwissenschaftlichen Klasse, (1):1-23, Mainz.

HILBERT, D. 1925. Über das Unendliche. Mathematische Annalen, 95(1925):161-190.

HUXLEY, J. 1968. Evolution in action. Hammondsworth: Penguin.

JONAS, H. 1973. Organismus und Freiheit: Ansätze zu einer philosophischen Biologie. München: VandenHoeck.

KANT, I. 1956 [1787]. Kritik der reinen Vernunft. 2. Ed. Hamburg: Felix Meiner. (References to CPR B.)

KANT, I. 1969 [1783]. Prolegomena einer jeden künftigen Metaphysik die als Wissenschaft wird auftreten können. Hamburg: Felix Meiner.

KITTS, D.B. 1974. Paleontology and evolutionary theory. Evolution, 28:458-472, Sept.

KLAPWIJK, J. 2008. Purpose in the living world. Cambridge: Cambridge University Press.

KLEE, R. 1997. Introduction to the philosophy of science. Oxford: Oxford University Press.

KLEIN, G. 1990. The atheist in the holy city. Cambridge: MIT. 
LAITMAN, J.T. 1985. Evolution of the upper respiratory tract: the fossil evidence. (In Tobias, P.V., ed. Hominid evolution., New York: Liss. p. 281286.)

LEINFELLER, W. 1966. Ueber die Karpelle verschiedener Magnoliales. TI. 1. Oesterreichische Botanische Zeitschrift, 113: 383-389.

LENNOX, J.C. 2007. God's undertaker. Has science buried God? Oxford: Lion.

LORENZ, K. 1973. Ueber tierisches und menschliches Verhalten: aus dem Werdegang der Verhaltenslehre. München: Piper. (Gesammelte Abhandlungen, Vol. 2.)

LORENZEN, P. 1976. Zur Definition der vier fundamentalen Meßgrößen. Philosophia naturalis, 16:1-9.

LORENZEN, P. 1989. Geometry as the measure-theoretic a priori of physics. (In Butts, R.E. \& Brown, J.R., eds. Constructivism and science. Dordrecht: Kluwer. p. 127-144.)

MAIER, A. 1949. Die Vorläufer Galileis im 14. Jahrhundert. Roma: Storia e letteratura.

MCGRATH, A.E. 1999. The foundations of dialogue in science \& religion. Oxford: Blackwell.

MEYER, A. 1964. The historico-philosophic background of modern evolutionbiology. Leiden: Bril.

MEYER, A. 1965. Gedanken zur Theorie und Philosophie des Organismus. Leopoldina, 10.

MEYER, A. 1966. Gedanken zur Theorie und Philosophie des Organismus. Leopoldina, 11.

MILLS, G.C., LANCASTER, M. \& BRADLEY, W.L. 2003. Origin of life and evolution in biology textbooks: a critique. (In Campbell, J.A. \& Meyer, S.C. Darwinism, design, and public education. East Lansing: Michigan State University Press. p. 208-219.)

MUNSON, R., ed. 1971. Man and nature: philosophical issues in biology. New York: Dell.

NARR, K.J. 1974. Tendenzen in der Urgeschichtsforschung. (In Luyten, N.A., ed. Fortschritt im heutigen Denken? Freiburg: Alber. Görres-Gesellschaft für Interdisziplinäre Forschung. Series: Grenzfragen, Vol. 4. p. 85-125.)

NARR, K.J. 1976. Cultural achievements of early man. (In Altner, G. \& Hofer, H. Die Sonderstellung des Menschen. Stuttgart: Fischer.)

NEURATH, O. 1959. Sociology and physicalism. (In Ayer, A.J. Logical positivism. New York: Free Press. p. 282-317.) (Originally published in Erkenntnis, 1931/32.)

OEING-HANOFF, L. 1976. Individuum, individualität - Hoch- und Spätskolastik. (In Ritter, J., Gründer, K. \& Gabriel, G., Reds. Historisches Wörterbuch der Philosophie. TI. 4. Basel-Stuttgart: Schwabe. S. 304-310.)

OPARIN, A.I. 1953. Origin of life. New York: Dover.

ORGEL, L.E. 1998. The origin of life: a review of facts and speculations. Trends in biochemical sciences, 23(1998):491-500.

ORGEL, L.E. \& SULSTON, J.E. 1971. Polynucleotide replication and the origin of life. (In Kimball, A.P. \& Orò, J. 1971. Prebiotic and biochemical evolution. Amsterdam: North-Holland. p. 89-94.)

OVERHAGE, P. 1972. Der Affe in dir. Frankfurt am Main: Josef Knecht.

POLANYI, M. 1967. Life transcending physics and chemistry. Chemical engineering news, 45:54-66, Aug.

POLANYI, M. 1968. Life's irreducible structure. Science, 160(21):1308-1312. 
POLANYI, M. 1969. Personal knowledge. Chicago: University of Chicago.

RAUCHE, G.A. 1966. The problem of truth and reality in Grisebach's thought, Pretoria: Van Schaik.

RENSCH, B. 1959. Evolution above the species level. London: Methuen.

RENSCH, B. 1968. Discussion remarks, attached to Von Bertalanffy: symbolismus and anthropogenese. (In Rensch, B. \& Schultz, A.H., Reds. 1968. Handgebrauch und Verständigung bei Affen und Frühmenschen. Symposium der Werner-Reimers-Stiftung für anthropogenetische Forschung. Bern: Huber. S. 172-173.)

RENSCH, B. 1969. Die fünffache Wurzel des panpsychistischen Identismus. Philosophia naturalis, 11.

RENSCH, B.1971. Biophilosophy. New York: Columbia University Press.

RENSCH, B. 1973. Gedächtnis, Begriffsbildung und Planhandlungen bei Tieren. Hamburg: Parey.

SCHINDEWOLF, O.H. 1969. Ueber den "Typus" in morphologischer und phylogenetischer Biologie. Wiesbaden: Monograph.

SCHINDEWOLF, O.H. 1980. Grundfragen der Paläontologie. New York: Arno.

SCHUBERT-SOLDERN, R. 1959. Materie und Leben als Raum und Zeitgestalt. München: Pustet.

SCHUBERT-SOLDERN, R. 1962. Mechanism and vitalism: philosophical aspects of biology. Ed. by P.G. Fothergill. Foreword to the American ed. by J.P. Doll. Trans. by C.E. Robin. Notre Dame: Indiana University of Notre Dame Press.

SILVER, B.L. 1998. The ascent of science. Oxford: Oxford University Press.

SIMPSON, G.G. 1969. Biology and man. New York: Harcourt.

SIMPSON, G.G. 1971. Man's place in nature. Section from "The Meaning of Evolution". Revised edition. (In Munson R., ed. Man and nature: philosophical issues in biology. New York: Dell. p. 268-278.)

SINNOTT, E.W. 1963. The problem of organic form. London: New Haven.

SINNOTT, E.W. 1972: Matter, mind and man: the biology of human nature. New York: Atheneum.

SOBER, E. 1987. The nature of selection: evolutionary theory in philosophical focus. London: MIT.

STAFLEU, M.D. 1980. Time and again: a systematic analysis of the foundations of physics. Toronto: Wedge Publishing Foundation.

STERELNY, K. 2001. Dawkins vs. Gould: survival of the fittest. London: Icon Books.

STRAUSS, D.F.M. 2006. Filosofiese tendense in die wordingsgeskiedenis van ons verstaan van die fisiese natuur. Akademie tydskrif vir natuurwetenskappe, 25(2):93-110.

STRAUSS, D.F.M. 2007. Did Darwin develop a theory of evolution in the biological sense of the word? South African journal of philosophy, 26(2):190-203.

STRAUSS, D.F.M. 2009. Philosophy: disciplines of the disciplines. Grand Rapids: Paideia.

TOL, T. 1995. Time and change in Vollenhoven. Philosophia reformata, 60(2):99-120.

TRINCHER, K. 1985. Die Dualität der Materie. Philosophia naturalis, 22(3):329342.

TROLL, W. 1951. Biomorphologie und Biosystematik als typologische Wissenschaften. Studium Generale, 4:376-389. 
TROLL, W. 1973. Allgemeine Botanik. Revised and extended edition. Stuttgart: Ferdinand Enke.

UNGERER, E. 1966. Die Wissenschaft vom Leben. Teil 3: Der Wandel der Problemelage der Biologie in den letzten Jahrzehten. Freiburg: Alber.

VAN DEN BEUKEL, A. 2006. Darwinisme: wetenschap en/of ideologie? (In Dekker, C., Meester, R. \& Van Woudenberg, R. Schitterend ongeluk of sporen van ontwerp? Kampen: Ten Have. p. 101-116.)

VAN HUYSSTEEN, J.W. 1998. Duet or duel? Theology and science in a portmodern world. Harrisburg: Trinity Press.

VAN HUYSSTEEN, J.W. 2006. Alone in the world? Human uniqueness in science and theology. Grand Rapids: Eerdmans.

VAN RIESSEN, H. 1970. Wijsbegeerte. Kampen: Kok.

VON BERTALANFFY, L. 1973. General system theory. Hammondsworth: Penguin.

VON FRITZ, K. 1945. The discovery of incommensurability by Hippasus of Metapontum. Annals of mathematics, 46:242-264.

VON WEISZÄCKER, C.F. 1993. Der Mensch in seiner Geschichte. München: Deutsche Theologische Verein.

WEINERT, F. 1998. Fundamental physical constants, null experiments and the Duhem-Quine thesis. Philosohpia naturalis, 35:225-251.

WELLS, J. 2003. Second thoughts about peppered moths. (In Campbell, J.A. \& Meyer, S.C. Darwinism, design, and public education. East Lansing: Michigan State University Press. p. 187-192.)

WOLF, K.L. 1951. Urbildliche Betrachtung. Studium Generale, 4:365-375.

WOLTERECK, R. 1940. Ontologie des Lebendigen. Stuttgart: Ferdinand Enke.

WUKETITS, F.M. 1990. Evolutionary epistemology and its implications for humankind. New York: State University Plaza.

ZYLSTRA, U. 2004. Intelligent-design theory: an argument for biotic laws. Zygon, 39(1):175-191.

\section{Key concepts:}

attempted synthesis:Christianity and evolution

continuity and discontinuity

Neo-Darwinism

origin of life

paleontology

schools of thought

\section{Kernbegrippe:}

denkskole

gepoogde sintese: Christendom en evolusie

kontinuïteit en diskontinuïteit

Neo-Darwinisme

ontstaan van lewe

paleontologie 